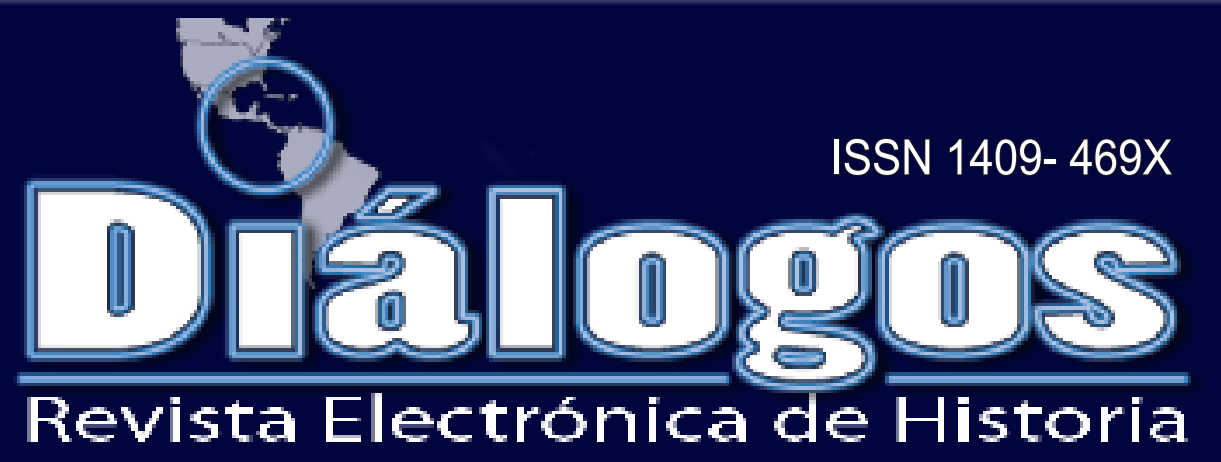

Escuela de Historia. Universidad de Costa Rica Vol. 13 No. 1 Febrero - Agosto 2012

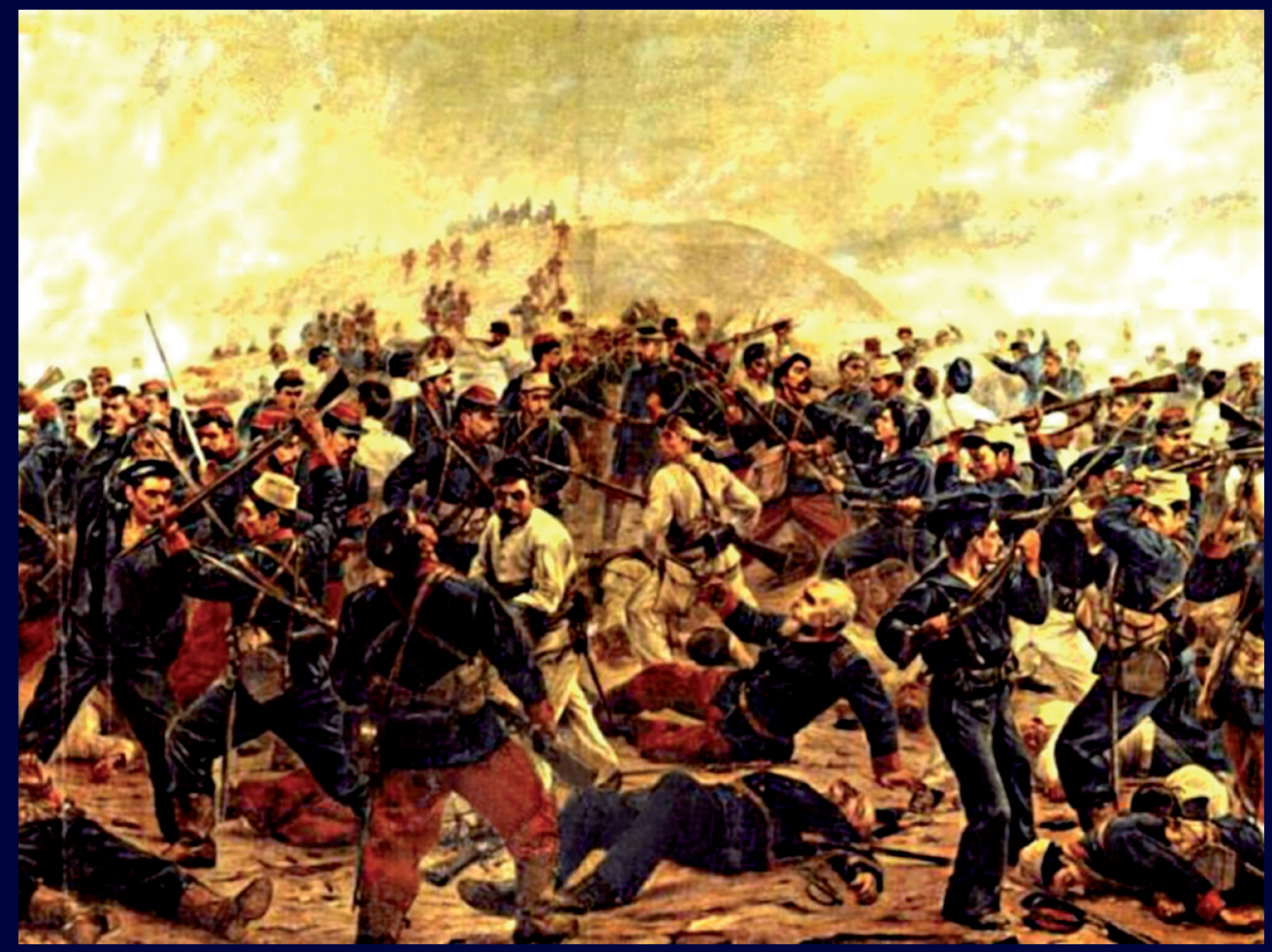

\title{
LA HISTORIA DEL CORPORATIVISMO EN EUROPA. APROXIMACIÓN A LAS FORMAS JURÍDICO-POLÍTICAS DE REPRESENTACIÓN DEL TRABAJO.
}

Sergio Fernández Riquelme.

Director de la Revista: Dr. Juan José Marín Hernández juan.marinhernandez@ucr.ac.cr

Editor académico: Dr. Ronny Viales Hurtado - ronny.viales@ucr.ac.cr Editor técnico: M.Sc. Marcela Quirós G. - marcela.quiros@ucr.ac.cr Asistente: Cindy Chaves U. http://historia.fcs.ucr.ac.cr/dialogos.htm 


\section{Miembros del Consejo Editorial:}

Dr. Juan José Marín Hernández, Catedrático. Director del Centro de Investigaciones Históricas de América Central. Universidad de Costa Rica.

Dr. Ronny Viales Hurtado. Catedrático. Historia Económica y Social. Universidad de Costa Rica. Director de la Escuela de Historia. ronny.viales@ucr.ac.cr

Dr. Guillermo Carvajal. Geografía Humana. Universidad de Costa Rica.

MSc. Francisco Enríquez. Historia Social. Universidad de Costa Rica.

MSc. Bernal Rivas Especialista en Archivística. Universidad de Costa Rica.

MSc. Ana María Botey. Historia de los movimientos sociales. Universidad de Costa Rica.abotey@gmail.com

\section{Miembros del Consejo Asesor Internacional:}

Dr. José Cal Montoya. Universidad de San Carlos de Guatemala.jecalm@correo.url.edu.gt

Dr. Juan Manuel Palacio. Universidad Nacional de San Martín.jpalacio@unsam.edu.ar

Dr. Eduardo Rey. Universidad de Santiago de Compostela.ereyt@usc.es

Dr. Heriberto Cairo Carou. Departamento de Ciencia

Política y de la Administración III - Universidad

Complutense de Madrid. hcairoca@cps.ucm.es

Dra. Rosa de la Fuente. Departamento de Ciencia Política y de la Administración III Universidad Complutense de Madrid rdelafuente@cps.ucm.es

Dr. Javier Franzé. Departamento de Ciencia Política y de la Administración III Universidad Complutense de Madrid. javier.franze@cps.ucm.es

Dr. Jaime Preciado Coronado Departamento de Estudios Ibéricos y Latinoamericanos. Universidad de Guadalajara japreco@hotmail.com

Dr. Gerónimo de Sierra. Vicerrector de la Universidade Federal da Integração Latino-Americana (UNILA) y Departamento de Sociología, Facultad de Ciencias Sociales de la Universidad de la República. geronimo@fcs.edu.uy

Dr. Antonio Palazuelos. Departamento de Ciencia Política y de la Administración III - Universidad Complutense de Madrid. palazuelosa@cps.ucm.es

Dr. Werner Mackenbach. Universidad Potsdam. werner.mackenbach@uni-potsdam.de
Dr. Guillermo Castro. Ciudad del Saber Panamá. gcastro@cdspanama.org

Dra. Natalia Milanesio. University of Houston.

nmilane2@Central.UH.EDU

Dr. Ricardo González Leandri. Consejo Superior de Investigaciones Científicas - España.

rgleandri@gmail.com

Dra. Mayra Espina. Centro de Estudios Psicológicos y Sociológicos, La Habana. mjdcips@ceniai.inf.cu

Dra. Montserrat Llonch. Departamento de Economía e Historia Económica Universidad Autónoma de Barcelona montserrat.llonch@uab.es

Dra. Estela Grassi. Universidad de Buenos Aires. estelagrassi@gmail.com

Portada:

Óleo de Juan Lepiani titulado Batalla de Arica (1880-Museo de los Combatientes de Arica) : Volumen 13- No. 1, artículo 2 "Sois vosotros valientes héroes. Somos nosotros simples humanos"... de David Angelo Coronado Canales. Fuente: http://members.tripod.com/ Guerra_del_Pacifico/ARICA3. html

"Diálogos Revista Electrónica de Historia" se publica desde octubre de 1999.

\section{Diálogos está en los siguientes repositorios:}

Dialnet

http://dialnet.unirioja.es/servlet/revista?tipo_busqueda=CODIGO\&clave_revista=3325

Latindex

http://www.latindex.unam.mx/larga.php?opcion=1\&folio=12995;

REDALYC

http://redalyc.uaemex.mx/src/inicio/FrmBusRevs2.jsp?iEdoRev=2\&cvepai=11

LANIC

http://lanic.utexas.edu/la/ca/cr/indexesp.html;

Repositorio de Revistas Universidad de Costa Rica http://www.latindex.ucr.ac.cr/

Directorio y recolector de recursos digitales del Ministerio de Cultura de España

http://roai.mcu.es/es/inicio/inicio.cmd

DOJAC Directory of open access \& Hybrid journals http://www.doaj.org/doaj?func=byTitle\&hybrid=1\&query=D

Biblioteca de Georgetown

http://library.georgetown.edu/newjour/d/msg02735.html

Asociación para el Fomento de los Estudios Históricos en Centroamérica

http://afehc.apinc.org/index.php?action=fi_aff\&id=1774 
Universidad de Saskatchewan, Canadá

https://library.usask.ca/ejournals/view/1000000000397982

\section{Monografias}

http://www.monografias.com/Links/Historia/more12.shtm

\section{Hispanianova}

http://hispanianova.rediris.es/general/enlaces/hn0708.htm

Universidad del Norte, Colombia

http://www.uninorte.edu.co/publicaciones/memorias/enlaces.html

Universidad Autónoma de Barcelona

http://seneca.uab.es/historia/hn0708.htm

Repositorio Invenia - Gestión del Conocimiento

http://www.invenia.es/oai:dialnet.unirioja.es:ART0000086144

Enlace Académico

http://www.enlaceacademico.org/biblioteca/revistas-en-formato-digital-centroamerica/

\section{Electronic Resources}

http://sunzi1.lib.hku.hk/ER/detail/hkul/3987318

Revistas académicas en texto completo

http://web.prw.net/ vtorres/

\section{Diálogos se anuncia en las siguientes} instituciones y sitios académicos:

\section{Maestroteca}

http://www.maestroteca.com/detail/553/dialogos-revista-electronica-de-historia.html

\section{Biblioteca de Georgetown}

http://library.georgetown.edu/newjour/d/msg02735.htm
Asociación para el Fomento de los Estudios Históricos en Centroamérica

http://afehc.apinc.org/index.php?action=fi_aff\&id=1774

Universidad de Saskatchewan, Canadá

https:/library.usask.ca/ejournals/view/1000000000397982

\section{Monografias}

http://www.monografias.com/Links/Historia/more12.shtml

Hispanianova

http://hispanianova.rediris.es/general/enlaces/hn0708.htm

Universidad del Norte, Colombia

http://www.uninorte.edu.co/publicaciones/memorias/enlaces.html

\section{Universidad Autónoma de Barcelona}

http://seneca.uab.es/historia/hn0708.htm

Repositorio Invenia - Gestión del Conocimiento http://www.invenia.es/oai:dialnet.unirioja.es:ART0000086144

\section{Enlace Académico}

http://www.enlaceacademico.org/biblioteca/revistas-en-formato-digital-centroamerica/

\section{Electronic Resources}

http://sunzi1.lib.hku.hk/ER/detail/hkul/3987318

Revistas académicas en texto completo http://web.prw.net/ vtorres/

La revista electrónica Diálogos es financiada por la Vicerrectoría de Investigación de la Universidad de Costa Rica
Citado en Dialnet - Latindex-

Redilac- Directorio y recolector de recursos digitales del

Ministerio de Cultura de España cc) creative 



\title{
LA HISTORIA DEL CORPORATIVISMO EN EUROPA. APROXIMACIÓN A LAS FORMAS JURÍDICO-POLÍTICAS DE REPRESENTACIÓN DEL TRABAJO.
}

\author{
Palabras claves \\ Corporativismo, función, organicismo social, sindicatos, técnica, trabajo.
}

\section{Keywords}

Corporatism, function, social organicism, technics, work.

Fecha de recepción: 27 enero de 2012 - Fecha de aceptación: 22 febrero de 2012

\begin{abstract}
Resumen
El trabajo siguiente presenta una aproximación historiográfica al desarrollo jurídico y político de la representación estatal del Trabajo en Europa. En su itinerario señalamos tres dimensiones de estudio (retrospectiva, perspectiva y prospectiva) siguiendo el paradigma de la Historia de las ideas, buscando el significado de las fórmulas corporativas como modalidad de la "política técnica". Así nuestra historia transcurre desde mediados del siglo XIX hasta los albores del siglo XXI; periodo donde subrayamos las principales ideas y los autores destacados, desde la hipótesis de la pluralidad doctrinal en su origen histórico, las coincidencias ideológicas entre ideologías supuestamente adversas como instrumento político-social, y la pervivencia de ciertos de sus postulados en el Estado social y de derecho actual.
\end{abstract}

\begin{abstract}
The present work approaches the historical approximation to the theoretical and institutional development of the juridical - political representation of the Work in the Europe of the 20th century. For it we establish three general phases (retrospective, perspective and prospective dimensions) in the configuration of the corporate formulae as modality of the "technical policy", from middle of the 19th century up to the whiteness of the 21 st century. In each of them, we establish the key ideas and the significant authors, showing the doctrinal plurality in his historical genesis, the doctrinal coincidences between supposedly adverse ideologies as political - social instrument, and the survival of certain of his manifestations in the current Social State.
\end{abstract}




\section{LA HISTORIA DEL CORPORATIVISMO EN EUROPA. APROXIMACIÓN A LAS FORMAS JURÍDICO-POLÍTICAS DE REPRESENTACIÓN DEL TRABAJO.}

Sergio Fernández Riquelme

\section{A MODO DE INTRODUCCIÓN. TÉCNICA Y POLÍTICA EN EL VIEJO CONTINENTE.}

Desde mediados del siglo XIX, el Derecho político europeo valoró la posibilidad de la representación política del Trabajo. Los hombres y las obras de este "tiempo histórico" (Koselleck, 2001: 9), que en los países ibéricos alcanzó una casi una centuria, parece hoy, historiográficamente, como un tema menor (tras la constitucionalización europea de los mecanismos de la negociación laboral colectiva) o como un tema proscrito (ante la "contaminación fascista" de las doctrinas fundamentales). Pero esta fórmula jurídico-política, como opción histórica, hizo fortuna, mutatis mutandis, en distintas escuelas de pensamiento jurídico-político del Viejo Continente fundadas en una particular interpretación de la teoría orgánica de la sociedad (tradicional-gremial, funcionalista); y generadas como instrumento para alternar o apoyar las vías representativas de la política demoliberal del novecientos y los mecanismos revolucionarios y antiparlamentarios del sindicalismo de clase. Y entre ellas surgió una plural doctrina político-social aun objeto de debate historiográfico, politológico y sociológico: el Corporativismo.

¿Pero como comienza esta Historia ${ }^{1}$ ?. El recurso a la Corporación como entidad de Derecho público, surgió ante el florecimiento doctrinal de la concepción orgánica-funcional de la Sociedad; concepción que respondía, básicamente, a un fenómeno no siempre advertido: la tecnificación de la política (como ciencia y como praxis) de la Europa contemporánea. El reconocimiento jurídico-político de la acción colectiva (sindical y patronal), la justificación de las prácticas tecnocráticas en la gestión y administración pública, así como la creciente influencia de los llamados "grupos de presión" en el diseño y control de ciertas áreas estatales, son algunos testimonios de la persistencia histórica de una tendencia (o "movimiento histórico") que demuestra como bajo los principios ideológicos establecidos por el sistema constitucional de la democracia de partidos, auténticos dogmas en la selección de los cauces de representación y participación política, se pueden documentar elementos teóricos y ciertas prácticas institucionales vinculadas no sólo a recursos burocráticos y tecnocráticos ajenos al ideal de la "soberanía popular", sino a mecanismos corporativos que determinan notables áreas de la intervención políticosocial $^{2}$. El estudio tanto del proclamado "recurso a los técnicos", pretendidamente 
desideologizados y suprapartidistas, tan en boga a comienzos del siglo XXI, como del epifenómeno del "neocorporativismo", rescoldo del sueño a un Estado corporativo, ha sido atendido en los últimos años desde categorías empíricas de alcance limitado (véase las tesis de las ciencia administrativa, el tradicional organicismo social o la recurrente conciliación de intereses organizados). Frente a la polisemia terminológica que ha caracterizado al fenómeno (identidad profesional, intervencionismo de Estado, proteccionismo económico, etc.), el Corporativismo aparece, bajo sus manifestaciones doctrinales y temporales diversas, como una auténtica doctrina político-social que propugnaban la "organización política y económica de la vida social", sobre la base del pluralismo de asociaciones representativas de los intereses y actividades profesionales (bien los modernos sindicatos, bien los viejos gremios), y en virtud de los nuevos principios políticos de función, representación y organización (Incisa, 1982). De esta manera podemos hablar del corporativismo como doctrina social fundada, históricamente, en la mediación entre trabajo (obreros) y capital (patronos), protagonistas de la moderna Cuestión social, con una finalidad declarada: la armonía social.

¿Y de qué manera se configuró el itinerario histórico del Corporativismo?. El desarrollo de las doctrinas e instituciones corporativas fueron surgiendo en Europa, desde la primera mitad del siglo XX, a raíz de la vinculación entre la naturaleza técnica de la política y las fórmulas ordenadoras del pluralismo social, respondiendo a la máxima sobre "lo político" cifrada por Max Weber [1864-1920]: la "Política significará pues, para nosotros, la aspiración (Streben) a participar en el poder o a influir en la distribución del poder entre los distintos Estados, o dentro de un mismo Estado, entre los distintos grupos de hombres que lo componen" (Weber, 1981). Una máxima que respondía, historiográficamente, al "tiempo histórico" donde se advertía el impacto del industrialismo y su técnica, convertida en "ideología" para Jürgen Habermas [1929-]; contexto en que las ideas e instituciones albergaban el reto de una nueva mentalidad social y una emergente tecnificación de la política: el cambio de "centro de gravedad" del espíritu europeo (Habermas, 1986). Así, la secuencia histórica de la civilización continental mostraba, como atisbó el polémico jurista alemán Carl Schmitt [1888-1985], como en el siglo XIX lo económico se situaba como nuevo Zentralgebiet en asociación instrumental con "la técnica". El progreso técnico acelerado acabó afectando a la totalidad de los problemas humanos, configurando una sociedad industrial y especializada, clasista y pluralista (Gesselschaft), definida en términos económicos, y explicada sobre la dialéctica capital y trabajo, y superadora del antiguo "espacio social dominado" analizado por Ernst Forsthoff [1902-1974]; pero este progreso elevado a "religión de los milagros técnicos", era el mismo responsable de los problemas de conflictividad característicos de la Sociedad industrial. Así los testimoniaba el sociólogo germano Werner Sombart [1863-1941]. 
En este contexto, dominado por una nueva "procura existencial" (Daseinvorsorge) y presidido por el mito de la lucha de clases", nacía el "remedio" interclasista y técnico del Corporativismo (Fortshoff, 1972). "Nuestras sociedades son o tienden a ser esencialmente industriales" por el "desenvolvimiento, desconocido hasta el presente, que han tomado, desde hace próximamente dos siglos, las funciones económicas". Estas funciones se transformaban, para Èmile Durkheim [1858-1917] en funciones sociales: se pasaba de las tradicionales funciones militares o administrativas a "una forma de actividad que se ha apoderado de un lugar semejante en el conjunto de la vida social", pero que carece de reglamentación basada en una clara acción moral (Durkheim, 1982: 5).

¿Pero cómo termina, o puede terminar, esta Historia?. Las fórmulas históricas de tecnificación política bajo modelos corporativos eclosionaron a mitad del siglo $\mathrm{XX}$, aspirando a resolver la antinomia presente en conceptuación de la dialéctica asociación-representación, ante el impacto de la técnica económica y de sus nuevos grupos socioprofesionales. Para ello insertaron una suerte de razonamiento de legitimación funcional tanto en la decisión ejecutiva como en la deliberación legislativa bajo regímenes monocráticos. Pero el nuevo escenario abierto tras la II Guerra mundial comenzó a valorar el recurso a los "políticos técnicos" dentro del Estado social y Derecho de Europa occidental, que superaban, a priori, las disfunciones de variabilidad (tiempo y voluntad) que conllevaba el sistema de elección por motivos ideológicos; y en la segunda, el viejo "corporativismo" autoritario mutaba en un "corporatismo" democrático que anulaba o completaba la oligarquización de la democracia de partidos, otorgando a las organizaciones profesionales y a sus representantes, de manera plena o de manera indicativa, capacidad de decisión política en temas económico-sociales (Molina, 2007)³.

Así pues, y desde el paradigma de la "historia de las Ideas", este artículo presenta una revisión historiográfica del desarrollo histórico-jurídico (retrospectiva, perspectiva y prospectiva) del Corporativismo como medio propio de las tendencias hacia la tecnificación de la política europea (Molina, 2007). Para ello sistematizamos las principales formas doctrinales sobre la participación y representación jurídico-política del "trabajo organizado" (corporativista), buscando su significado histórico en el espacio y el tiempo ${ }^{4}$.

\section{ITINERARIO DEL CORPORATIVISMO: RETROSPECTIVA, PERSPECTIVA, PROSPECTIVA.}

Tres son las dimensiones de estudio historiográfico que establecemos para intentar descifrar el significado del Corporativismo, en sus ideas y sus obras: retrospectiva (de la autoorganización del pluralismo social, a la participación política del 
trabajo en el sistema constitucional), perspectiva (transformación autoritaria del Estado) y prospectiva (representación neocorporativa de intereses).

\section{Retrospectiva: el sueño de una "democracia social".}

La Ley Le Chapelier [1791] puso fin a la dimensión económico-profesional del Antiguo Régimen. Los viejos gremios de origen medieval, así como sus sistemas de control y promoción interna, desparecían legalmente, ante el triunfo aparente del laissez-faire. A los derechos políticos individuales se sumaban los económicos y los sociales; por ello, la corporaciones profesionales y artesanas dejaban de tener "sentido histórico" y reconocimiento jurídico ${ }^{5}$. Pero las primeras consecuencias socio-comunitarias del impacto del industrialismo, en términos de estructura y relaciones, así como en nacimiento de las primeras organizaciones obreras mutualistas, llevaron parejas un lento y desigual "renacimiento corporativo"; un proceso que situaba a la Corporación como sistema de organización de la nueva configuración industrial (de claras reminiscencias positivistas), o como medio ordenación (bajo el signo del iusnaturalismo). En ambos casos, las fórmulas corporativas anunciaban, bajo formas aún indefinidas en sus límites doctrinales, una transformación de la política en clave de autoorganización social y constitucionalización del mismo en su historia.

La primera dimensión de este estudio historiográfico nos remite a una amplia retrospectiva de sus orígenes, que podemos situar, como hemos apuntado, en las doctrinas político-sociales fundadas en el ideal del organicismo social; ideal presente en la Escuela histórica alemana, en el Magisterio social católico y en el neotradicionalismo mediterráneo (legitimismo francés, carlismo español), en la "organización de productores" (L. Blanc y H. de Saint-Simon), en el movimiento mutualista (J. P. Proudhon, Ch. Fourier, R. Owen, W. B. Greene), en el guildismo inglés (OPenty, Orange) o en la recuperación del "gremio medieval" (O. von Gierke). El trabajo se convertía, de manera básica, en el criterio básico para la organización de la forma de gobierno (formas alternativas de democracia) y de la forma política (negación o superación de la idea de Estado soberano y unitario); así, la política se configuraba bajo el prisma del pluralismo social generado por la nueva "relación económica industrial", y ello explicaba tanto la crítica colectivista a la economía capitalista como la crítica organicista a la democracia liberal. Esta autoorganización participaba, como otros movimientos comunitaristas (socialismo utópico o democracia social, mutualismo o sindicalismo), de las claves de la "época de la política social": critica moralizante de la Economía política, por el cuestionamiento de los principios del Liberalismo político, y por el desarrollo sin precedentes del intervencionismo socioeconómico estatal.

En este sentido, la primera proyección "cultural" del organicismo social fue obra del idealismo romántico y antiindividualista de la "Escuela histórica" alemana. 
Ante la Revolución política renació el interés, a través de la Historia del derecho y de la filosofía, por las formas de ordenación gremialista, asidero historicista contra los esquemas del liberalismo doctrinario, institucionalizados finalmente por la Revolución de 1830. Ante la posterior Revolución social, un nuevo ideal ético y una nueva "solidaridad social" será bandera de una generación que reaccionará a los ideales individualistas de las revoluciones liberales, retomando el ideal organicista de Herder, Möser y Fichte. La magna obra de Georg Wilhelm Friedrich Hegel [1770-1831] abrió el camino de recuperación de la realidad de sistemas de organización y representación corporativa, pero marcó la tendencia germana de sometimiento a la unidad soberana del la ética de Estado. En Hegel el corporativismo aparecía como medio auxiliar para alcanzar la verdadera unidad y armonía del "cuerpo social", y reflejar políticamente la "sociedad poliárquica" (Hegel, 1946). El "organicismo metafísico" desarrollado en Enciclopedia de la ciencia filosófica (1817) y Fundamentos de la filosofía del Derecho (1821), apuntaba un sistema político-social que agrupaba a los ciudadanos en tres grandes "Stände" (famillias, trabajo u corporaciones), las cuales articulaban la representación política estatal como Ständeversammlungen (Asambles estamentales) ${ }^{6}$.

En esta escuela, será el jurista e historiador alemán Otto von Gierke [18411921] $]^{7}$ quién recuperó, para el derecho político del siglo XIX, la noción de Corporación medieval y sus principios de representación, soberanía y organización grupal (Gierke, 1985). El primer volumen de su obra Deutsche Genossenschaft (1868) marcará el punto de inflexión. La clave la encontró en la idea del jurista calvinista J. Althusio: la "consonciación"; ésta concepción del Estado y la Sociedad" (Johannes Althusius und die Entwiklung der naturrechtlichen Staatstheorien, 1880) se fundía con las influencias románticas e historicistas del Derecho Común alemán (Der Humor im Deutschen Recht, 1887). El llamado "vater des Genossenschatfrecht", combinaba la doctrina del iusnaturalismo y el concepto de la organización profesional, implícito en el Derecho político liberal, para recrear esta noción de Corporación como "teoría legal de la personalidad de grupo". A diferencia de otras ideas sobre asociación, comunidad o cooperativas "autoorganizadas", Gierke defendió una idea grupal con poderosos antecedentes históricos: la corporación de origen medieval germano. Esta idea partía del hecho objetivo de los "derechos de las comunidades", fundado en la tradición jurídico-política germano-cristiana, y legitimado por una función adecuada al objetivo de la "ley pública": la descentralización política (Gierke, 1922: 61).

En este esquema, el principio de la organización del poder se fundaba, para Gierke, en la doble representación monócratica y democrática (corporativa); así se secularizaba "la soberanía del poder" y se defendía la necesaria limitación de todo poder constitucional a través de la función estable del cargo público y la corporación (Hofmann, 2004). Su "theorie der Genossenchaft" asumía la idea 
de sociedad política de Althusio: la sociedad orgánica, en su diversidad, condicionaba los derechos estamentales del pueblo a su realización, a través de la representación corporativa. Por ello Gierke subrayaba que el equilibrio medieval entre Estado, Iglesia y Sociedad se articulaba a través de Corporaciones, dotadas de unos poderes "que no eran derechos privados de una suma de individualidades, sino el derecho público a una asamblea"9. La fusión del derecho común alemán y la teoría romano-canónica hacían en un solo cuerpo Doctrina del Estado y la Doctrina de la Corporación. Según esta teoría, los pueblos alemanes medievales organizados en Verbänden, creaban corporaciones superiores o genossechaftlichen Verbänden (Sippe y Familienbund) como órganos del cuerpo social "total" (Körperschaften) ${ }^{10}$.

La "fusión orgánica" de Gierke remitía a un época medieval dónde las instituciones temporales y espirituales no eran más que "corporaciones superiores" de un sistema social orgánico hecho doctrina política; ambas se encontraban entrelazadas en la "doctrina medieval del Estado y de la Sociedad". La jurisprudencia recogía la tradición popular germana y la conciliaba con la doctrina romana de las corporaciones. En ella, la Monarquía era una institución representativa y un oficio ${ }^{11}$, condicionada por la concepción comunitaria de la soberanía popular, la representación estamental y la ley natural. La soberanía popular comunitaria, o "derecho de las mayorías" para Gierke, era reconocida en los actos del "cuerpo político" y en una serie de "derechos corporativos" como instrumento en la relación entre las Comunidades políticas y el Estado. Las "leyes corporativas" sancionaban "definitiva y legalmente, la idea del ejercicio de los derechos del pueblo en una Asamblea representativa, junto a los derechos del gobernante": una Asamblea estamental con elección de base orgánica en "cuerpos colegiados a imagen de los electores del Imperio y de los Cardenales en la Iglesia". Así nació y así era la "nación de guildas" reconstruida por Gierke.

El origen estaba claro para Gierke. La corporación medieval se concibió como freno a las apetencias de la Iglesia en convertirse en "el verdadero Estado", y del poder temporal de situarse por encima de la ley natural; mediaba así entre el absolutismo papal y el absolutismo imperial ${ }^{12}$. La "vieja idea germana del Estado de Derecho" restringía las aspiraciones absolutistas del poder político y del eclesiástico establecidas por el Derecho romano. De esta manera, la "unidad de la humanidad" ordenada orgánicamente en la Sociedad, requería de una organización política orgánica a su vez. "La armonía de la era del feudalismo" se basaba en situar a la "Comunidad" como fundamento del "sistema legal del Estado". Las "partes sociales" se repartían la Soberanía popular con una Monarquía representativa de origen divino. Esta soberanía popular (no individual sino grupal/estamental) se reconocía en un sistema jurídico capaz que aceptaba la capacidad de Representación y la Personalidad de las Corporaciones. Este sistema evitaba la "soberanía formalmente omnipotente" (el monarca que asume el poder ejecutivo y legislativo) 
o a la "formal omnipotencia del legislativo" (tiranía de la soberanía popular a través de la separación de poderes). El "Derecho de la sociedad precedía a todo Derecho estatal”, concluía Gierke (1922: 33) ${ }^{13}$.

Esta creación fue introducida, con gran éxito, en el mundo socialista británico por su discípulo Maitland; con los guildistas, la Corporación pasaba a ser ya "persona real y legal", tal como la definieron Figgis y William James. Gierke anunciaba con ello una fórmula corporativa del Derecho social (L. Duguit, E. Durkheim, A. Menger, M. Hariou, etc.), cuya fórmula se definía de la siguiente manera: el "Derecho de la sociedad precedía a todo Derecho estatal". Pero la Kulturkampf desplegada por Otto von Bismarck llevó a la proscripción del organicismo social de origen católico, y por ende, de las fórmulas pluralistas ligadas al corporativismo.

Pero la primera proyección político-social de envergadura se dio en la vecina Francia. "Si el municipio ha perdido su autonomía en el Estado y el mercado local se ha integrado en el Mercado nacional, ¿no es legítimo pensar que la Corporación deberá también sufrir la transformación correspondiente y llegar a constituir la división estamental del Estado, la unidad política fundamental?". La respuesta de Durkheim a esta pregunta delimitaba los rasgos de la Corporación moderna: el "órgano esencial de la vida pública" que solucionaba el problema más grave de la estructura de las sociedades europeas: la anomia social. "Una sociedad compuesta de una polvareda infinita de individuos inorganizados, que un Estado hipertrofiado se esfuerza en encerrar y retener -apunta Durkheim- constituye una verdadera monstruosidad sociológica". Por ello ya no se hablaba de la corporación territorial de reminiscencias medievales, sino de una nueva agrupación profesional: "los asuntos territoriales solo afectan a la sociedad si coinciden con los asuntos profesionales, ya que nuestra actividad se extiende más allá de los límites geográficos" (Durkheim, 1982: 23).

Ambas dimensiones fueron interrelacionadas, posiblemente, en la obra de Claude-Henri Rouvroy, conde de Saint-Simon [1760-1825]. Saint-Simon, tras advertir la relevancia del industrialismo en la sociedad del novecientos, desarrolló una fórmula político-socia donde la técnica y la corporación profesional se convertían en el criterio básico en la configuración política nacional ${ }^{14}$. Así, en La industria, El sistema (1823), su texto capital, contemplaba la industrialización no sólo como un signo de desarrollo y abundancia, sino especialmente como la base de un nuevo sistema político-social. En este último, la propiedad privada se respetaba en función de su interés social, el salario se vinculaba a la productividad, se postulaba la abolición del derecho a la herencia y las restricciones a la labor de los comerciantes. Este sistema ensalzaba la figura del productor o industrial (trabajadores y empresarios) frente a los no-productores (que agrupaban a nobles y terratenientes, comerciantes y "gandules"), y limitaba la acción del Estado a favorecer la difusión de la mentalidad industrial y reorganizar la sociedad bajo los principios del industrialismo. Su 
programa político se formulaba en estos términos: un Gobierno de tres ministros, que hayan ejercido durante varios años la profesión de industriales y una Cámara de industria asesora, que determinará el presupuesto y el empleo de los fondos públicos, y un Instituto educativo que organizará una enseñanza laica, obligatoria e igualitaria.

Asimismo, frente al neorromanicistismo germano y al positivismo galo, el Magisterio Social católico elaboró una de las más detalladas propuestas corporativas, base para ulteriores formulaciones en la Reforma social o en la Reacción neotradicionalista ${ }^{15}$. El intenso proceso de secularización en distintos países de tradición católica, capitalizado por liberales y socialistas, hizo adoptar a gran parte de catolicismo europeo, hasta el Concilio Vaticano II [1959-1965] un modelo propio y alternativo de ordenación político-social: el corporativismo ${ }^{16}$. A este fenómeno respondió la primera Encíclica social y obrera de la Iglesia Católica, la Rerum Novarum, promulgada por el papa León XIII [1810-1903] en 1891. Ante los efectos de pobreza y opresión sobre ciertos grupos obreros, y la capitalización de los mismos por el sindicalismo colectivista, desde el Magisterio social católico plantearon organismos "sindicales mixtos" capaces de articular un futuro modelo corporativo ${ }^{17}$.

Posteriores Encíclicas papales desarrollaron esta línea: Dicturnum (1881) sobre el origen del poder, atacando el absurdo pacto social, Inmortale Dei (1885) sobre la constitución cristiana de los Estados, y Libertas (1888) que ataca la falsa libertad del Liberalismo. Pero tanto el sindicalismo católico como el ideal de la corporación interclasista tuvieron escaso recorrido, pese a notables éxitos en áreas locales y agrarias, ante los sindicalismos de masas y de clase, y ante la progresiva institucionalización estatal del "hecho sindical". Aunque todo comenzó a cambiar con la publicación de la Encíclica Quadragesimo Anno (1931), bajo el papado de Pío XI [1857-1939].

Esta primera fórmula histórica nos adentra en las claves del "expediente técnico", tanto en sus orígenes, como en su desenvolvimiento. Frente al criterio ideológico, presente en la denunciada como "democracia estadística", los diferentes teóricos de la tecnificación introducían, en primer lugar, criterios funcionales en la gestión del poder ejecutivo, resaltando el criterio meritocrático como seña de identidad de una burocracia estatal competente en la gestión ejecutiva, en relación a la formación académica y a la competencia profesional (siendo representativo el positivismo sociológico de Augusto Comte [1798-1857], el cual tras contemplar la sociedad industrial, científica y tecnológica como fruto de toda la historia universal, establecía la conclusión de la necesidad de una dirección tecnológica y no ideológica de la sociedad); o subrayando, en segundo lugar, la supervivencia del organicismo social, en función del principio de subsidiariedad de las comunidades naturales o agrupaciones profesionales en la elección del poder legislativo, frente 
a los partidos políticos (en función de los "ámbitos naturales" de pertenencia: la familia, el municipio, y especialmente la profesión) ${ }^{18}$. Por ello, o bien se corregían los modelos políticos democrático-parlamentarios, y por ende su forma estatal correlativa, añadiéndole nuevos adjetivos (orgánica, social, industrial), o bien se negaba por formas decisionistas y monocráticas fundadas, en gran medida, en objetivos de desarrollo material indicativo y planificado.

Esta primera etapa del corporativismo, social o asociativo, participaba de las dinámicas de "ruptura" de la tradición de una forma política, el Estado moderno, al que Schmitt definía como el "portador del más ambicioso de todos los monopolios, el de la decisión política" (Schmitt, 1999: 40). H.J. Laski [1893-1950] en su primera fase doctrinal, asumía una "teoría pluralista del Estado" que negaba que ese mismo Estado fuera una asociación humana superior y soberana respecto al resto de asociaciones; era otras más de las agrupaciones sociales, con funciones determinadas y limitadas que no implicaban "el derecho de soberanía" (Laski, 2002: 76).

De manera complementaria, esta técnica corporativa superaba o completaba el principio cuantitativo del Individuo (sufragio universal) como criterio de participación; era el reflejo del principio de estabilidad que conllevaban los grupos sociales de naturaleza específicamente profesional, o de más amplia vinculación orgánica ("cuerpos intermedios y naturales" entre Estado e Individuo). También lo hacía con el principio cualitativo de la Ideología como criterio de elección, fundándose en los valores funcionales de función y servicio, contenidos en su definición orgánica y técnica del grupo social. La Corporación sustituía o completaba al Partido político como medio de representación, pero también se alzaba frente al "socialismo de Estado", que negaba la participación política de los "cuerpos sociales" en beneficio de una todopoderosa burocracia que hacía suyos los resortes del poder ${ }^{19}$. De esta manera anunciaba nuevas modalidades políticas donde la representación y participación residían, en última instancia, en la pertenencia a esos organismos de naturaleza económica (democracia llamada sindical, funcional, industrial, orgánica) ${ }^{20}$.

Este proceso mostraba que "la lucha pasa de la esfera económica a la política" cuando "ganaba la fuerza suficiente para agrupar de un modo efectivo a los hombres en amigos y enemigos". La "politización de lo económico" conducía, directamente, a la implantación de consideraciones económicas en los principios de actuación de un "Estado económicamente neutral en apariencia", señalando una "nueva sustancia de la unidad política". A ello responde el nacimiento de la primera teoría pluralista, ruptura directa de la "concepción unitaria de la soberanía" (Schmitt, 199: 67); un pluralismo cualitativamente distinto del pluralismo ideológico de los partidos liberales y del sindicalismo de raíz marxista o bakunista. El sindicalismo francés de Georges Sorel [1847-1922] (Le mouvement socialiste, 1907), el solidarismo jurídico de León Duguit [1859-1929] (L’Etat, 1901) y Maxime Leroy [18731957] (Le transformations de la puissance publique, 1907), y la teoría pluralista 
británica de G. H. D. Cole [1889-1959] negaban esa unidad soberana del Estado, refundando la política sobre grupos sociales y realidades económicas. La empresa corporativa participaba así, de la tendencia histórica de desmitificación del Estado, como forma política, perfecta, única y universal (Negro, 1995).

Pero además, como bien apuntó Lorenz von Stein [1815-1890], la tecnificación propia de la Sociedad Industrial, colaboró en la conversión de la Política convirtió en Política social ${ }^{21}$. Los problemas económicos (competencia) y sociales (lucha de clases) devenían en problemas políticos, pero no en clave ideológica (partidista), sino en realidades sociolaborales y planteamientos técnicos. Ante una sociedad definida en términos dualistas (capitalistas o socialistas), el corporativismo pareció operar como un elemento neutralizador de los "nuevos problemas" sociales entre clases sociales (obrero y empresario), concebidas como entidades económicas (trabajo y capital). El hecho sociológico y el episodio económico situaban a la Corporación como el instrumento para una Política social a veces sometida a los imperativos de ucronías gremialistas o utopías industriales ${ }^{22}$.

El punto común de estas doctrinas se situaba en negar, epistemológicamente, la "personalidad jurídica distinta y superior" del Estado y en rescatar la validez sociológica de la "constitución orgánica de la sociedad". Así llegaban, tras definir a la Sociedad como "regla social" nacida de un conjunto plural de vinculaciones e identidades individuales, a considerar al Estado como otra corporación más -tal como plantea al solidarismo de Duguit ${ }^{23}$ - coordinadora, a lo sumo, de distintas obligaciones y lealtades comunitarias. Para Schmitt, este "pluralismo despolitizado" se hacía visible en la coordinación entre asociaciones profesionales y sociedades religiosas" frente al Estado, hecho patente en Gran Bretaña (J. Neville, Churches in the Modern State, 1913). Estas teorías pluralistas coincidían también en buscar la unidad en virtud de un federalismo "desde abajo", nunca bajo la virtud pacificadora de la majestad y el monopolio político de una pasada unidad suprema y soberana. Su crítica a las "hipertrofias" del Estado moderno pretendía un cambio sustancial de su propia entidad jurídico-política; los liberales organicistas pretendían convertirlo en un simple organismo coordinador, los sindicalistas en un tipo especial de Estado industrial y los comunitaristas en una federación de asociaciones (Verbände) sociales y profesionales.

La "autoorganización de la sociedad" suponía para una fórmula de despolitización y neutralización de origen económico (Schmitt, 1999: 111); sus pretensiones de racionalización técnica de la vida colectiva afectaban a "lo político" como Estado soberano primero y como Estado neutral liberal después. Sociedad y Estado, economía y política se fundían en un nuevo régimen armónico y pluralista basado en la noción de la corporación. Se superaba la distinción "soberana" de lo político: la capacidad última para distinguir entre el amigo y el enemigo (o sentido de marcar el grado máximo de intensidad de unión o separación, de una asociación 
o una disociación). El Estado se convertía en una corporación más, en un ámbito neutral de compromisos entre agentes e interlocutores sociales (o organisierter Interesen); paralelamente también se superaba las pretensiones ideológicas de la representación democrática pura, la lucha por el "Sufragio universal" 24 . A este respecto, Duguit llegaba a plantear que un régimen político ajeno a toda forma estatal convencional. En Le droit social et le droit individuel et la transformation de 1'Etat (1909), anunciaba que estaba "en camino de elaborarse una sociedad nueva", basada en el rechazo del "derecho subjetivo" como noción básica del sistema político, y en una regla social de "interdependencia". Sobre ambas nacía una "ley orgánica de la sociedad", objetiva y positiva, por encima de la voluntad de los individuos y de la colectividad; sobre la misma se fundaba la transformación del Estado mediante una organización social basada en la descentralización o federalismo sindical. El sindicato se convertía en la corporación elemental de la estructura jurídica; pasaba de ser un "movimiento clasista" a dirigir funciones concretas capaces de limitar la acción del gobierno central (Duguit, 1909: 186).

Por ello, el corporativismo iba un paso más allá de la pretensión sindicalista y de la capacidad partidista. Las diversas escuelas de pensamiento corporativistas o "sistemas de cultura" (organicistas y funcionalistas), coincidan en trasladar la "pluralidad de vínculos éticos y materiales del individuo" al campo de la representación política. Se hablaba de una democracia orgánica o democracia corporativa (también llamada industrial o sindical), caracterizada para Pierre Rosanvallon por "des éléments de démocratie corporative se sont ainsi progressivements et discrètement édifiés en marge des institutions classiques de la démocratie parlementaire" (Rosanvallon, 1998: 168).

Pero pese a las tesis para o antiestatales de buen número de corporativistas de primera hora, este pluralismo devino en realidad política, en alternativa estatal. Sus propósitos manifiestos de "tecnificación de la política" (antidecisionista, antipartidista) solo reflejaban, políticamente, la división funcional del trabajo y criterios económicos de gestión funcional; ningún régimen antiestatal vio la luz. C. Schmitt señalaba que si bien tomaban sus motivos de distintos dominios conceptuales ajenos a lo "político" (religiosos, económicos, culturales, etc.), "no existe ninguna sociedad o asociación política" fuera de la unidad política esencial del tiempo presente: el Estado. Aquí comienza, sin límites cronológicos bien precisos, el tránsito de un corporativismo social al corporativismo estatal; su fase de transición será el intento del liberalismo social de reforma constitucional del Rechtstaat. Gierke no sólo concibió la reconstrucción historiográfica de la "corporación medieval", sino que posibilitó las bases empíricas su conceptuación "persona legal" para la nueva sociedad industrial; la forma política podría, como fue hasta el siglo XIII, situar parte de su soberanía, de su representatividad y de su organización en las "comunidades naturales". La corporación se convertía, así, en un organismo de derecho público (Gierke, 1922: 6). 
La Corporación se integró, posteriormente, en el sistema constitucional abierto por Weimar, como instrumento representativo ya no sólo para la reforma social, sino especialmente en la reforma constitucional. Tras el ocaso de gran parte de la vía autoorganizativa, el corporativismo se configuró, a todas luces, como una modalidad histórica de Estado social, parcialmente realizada. Los corporativistas fueron asumiendo la necesidad de la "ética de Estado" (Staatethik) para hacer realidad la pluralidad organizada corporativamente. Pese a la persistencia de un corporativismo asociativo residual (solidarismo, tradicionalismo, guildismo), este instrumento se orientó a la integración, bajo la égida de la forma política estatal, de la reivindicación, participación y movilización de los grupos sociales, clasistas o profesionales. Se pretendía, como señala Rosanvallon, una "démocratie substantialiste" (Rosanvallon, 1988: 221).

El constitucionalismo reformista de los años veinte, impactado por los actos e ideas del "movimiento sindical" francés, suministró innumerables recetas corporativizadas para la racionalización de la desordenada vida parlamentaria del Interbellum $^{25}$. Junto a propuestas sobre sistemas representativos bicamerales (A. G. Posada [1860-1944]) y Comisiones técnicas (G. Jellinek [1851-1911]), se sucedieron la creación de un régimen de sindicatos y profesiones que directamente destruía toda noción de Estado Soberano (Duguit), de un régimen político fundado en la idea de "Democracia orgánica" (S. de Madariaga [1886-1978]), de un Estado corporativizado de confesionalidad católica o de un Estado centralizado corporativamente donde el nacionalismo autoritario fundía Sociedad y Nación (Fernández Riquelme, 2009).

Así resultaba el pluralisticher Staat o Estado pluralista de la vía constitucional, bifurcado en dos direcciones: de un lado se postulaba un régimen sindicalista que negaba totalmente la soberanía estatal (León Bourgeois [1851-1925]); de otro, propuestas de reconocimiento constitucional de la representación política profesional y sindical o la creación de organismos laborales paritarios (Fernando de los Ríos [1879-1949], Julián Besteiro [1870-1940]). Dentro de la primera corriente, G. D. H. Cole defendía la necesidad del desplazamiento de las estructuras demoliberales hacia un sistema basado en la consideración de los gremios como los únicos organismos con capacidad administrativa y representativa (Cole, 1974). La organización política del futuro se fundamentaría, según Cole, en las "uniones gremiales" o poderes independientes reconocidos por un Estado, visto no como el centro de la organización social, sino como una de sus tantas instituciones; estas uniones representarían las múltiples formas asociativas e institucionales de la compleja comunidad extraparlamentaria (frente a las concepciones simplificadas del parlamentarismo democrático).

Frente al corporativismo encerrado en los viejos esquemas autoorganizativos (solidarismo, guildismo), la corriente propiamente constitucionalista buscará 
mecanismos para conciliar la realidad de democracia parlamentaria y la aspiración a la democracia profesional, económica u orgánica. Sobre diferencias doctrinales existía un objetivo común: el reconocimiento de los espacios de autonomía de los grupos socioeconómicos y el establecimiento de mecanismo concretos de representación corporativa (segunda cámara "del trabajo", Consejos Económicos con representación corporativa, Comisiones con funciones técnicas consultivas). El respecto que cada "unidad social" (sindical, religiosa, profesional) podría otorgarse un Derecho propio dentro de "un sistema político de solidaridad" (García Canales, 1977); con ello se completaba la democracia política institucional con la democracia social y económica desplegada por grupos e individuos. Este ideal del jurista español Posada compartía la necesidad de la integración corporativa del nuevo pluralismo surgido directamente de la movilización económica de la guerra y de la presión autoorganizada del movimiento obrero, pero reformando y no transformando el viejo sistema constitucional y su Derecho político. Con su "teoría de las funciones" del Estado fundamentaba la "reconstitución de la soberanía del Estado", mediante la combinación de democracia parlamentaria y la legitimidad representativa del pluralismo socioeconómico (tal como se planteó en Weimar). Para Posada resultaba una necesidad técnica introducir la representación y participación corporativa (Posada, 1891); una "federación de organizaciones específicas" de naturaleza social y económica ayudaría a la renovación del Estado al asumir funciones descentralizadas (Posada, 1905).

\section{Perspectiva: Autoridad y jerarquía en el Estado corporativo.}

La tercera dimensión nos ofrece la perspectiva que ha marcado el devenir del Corporativismo durante los últimos años. Durante la llamada "Guerra civil europea"26, la corporación apareció, doctrinal e institucionalmente, como instrumento estatal de administración de las relaciones sociolaborales. Evolucionó así, en numerosas naciones europeas, de una solución constitucional tendente a mejorar el funcionamiento del Estado liberal (integrando políticamente el pluralismo social), a una solución autoritaria que sometía toda pluralidad organizada a la "unidad de mando". En esta coyuntura, el corporativismo se vinculó a la naciente contrarrevolución nacionalista, que lo definió para la posteridad, tanto en la historiografía como en la ideología, en "solución fascista".

Este itinerario nos conduce ahora, tras el fin de la Primera Guerra mundial, al tránsito de la pretendida vía constitucional hacia la estatización del corporativismo por el influjo de cierta interpretación del idealismo hegeliano, la nacionalización de una parte del socialismo y una renovación puntual del tradicionalismo. En Austria, Italia, España, Francia (Vichy) o Portugal se fueron desplegando proyectos de "reconstitución" nacional sobre un sistema corporativo que pondría, en mayor 
o menor medida, la pluralidad socioeconónomica al servicio de una concepción unitaria y jerárquica de la Nación, ajena a las formas superadas de pluralismo político y sindical. Con notables diferencias, en estos países se asistirá al intento de conciliación de la "subsidiariedad" de los grupos sociales (profesionales, tradiciones, burgueses, clases medias) y la "unidad de mando" del Estado, con suerte desigual. A este respecto, el papel político del corporativismo respecto a la forma estatal fue ambivalente: instrumento de integración política de la sociedad orgánica, modificando o suprimiendo el artificio del Estado; o instrumento estatal de integración de dicha sociedad, vinculándola a una Nación unitaria y jerárquicamente articulada ${ }^{27}$. Para E.L. LLorens [1886-1943] la conexión entre política y técnica contenida en esta fórmula de "corporativismo de Estado", era un de los rasgos característicos en esta época: el camino hacia la dictadura ${ }^{28}$.

Para Ch. S. Maier [1939-], su identidad antiliberal y anticapitalista fue parcial y temporal, derivada de la "contaminación fascista" antes señalada (Maier, 1988: 26). Nacía una "solución estatal", autoritaria o totalitaria, de control del pluralismo social y económico, proclamando la "muerte del Estado liberal y la amenaza del Estado socialista". En esta línea aparece la estatificación del corporativa en fórmulas sindicalistas verticales (nacionalsindicalismo español, legionarismo rumano, e incluso en los Soviets rusos), y en organizaciones tendentes a la integración de socialismo y nacionalismo (véanse los orígenes del fascismo italiano). En este punto es ineludible señalar la construcción de Estados corporativos desde la izquierda política y social, especialmente en Hispanoamérica ${ }^{29}$; el Justicialismo argentino, el gremialismo chileno y el PRI mexicano son tres claros ejemplos al respecto ${ }^{30}$.

Maier cifró, por ello, a esta época como el tránsito "de la Europa burguesa a la Europa corporativa" (Maier, 1988: 27); una época donde se postulaba la integración del trabajo organizado bajo un sistema de negociación controlado por el Estado, y la descentralización funcional de la administración estatal como único criterio de representación político-social. Pero en esta época estatista, el paradigma más relevante del corporativismo integral y puro colocaba al Estado como un órgano más al servicio de la Nación, con una doble posición funcional como "corporación estricta" y como "supercorporación". Esta teoría integral de Mihail Manoilescu [1891-1950], dónde "las corporaciones eran las únicas fuentes de todo poder" y "deben concurrir a constituir el Estado" (Manoilescu, 1941), fue rechazada en su época histórica, pero resurgió paradójicamente treinta años después (Fernández Riquelme, 2005).

\section{Prospectiva: la representación de intereses organizados o posibilidad neocorporativa.}

En los estertores del siglo XX, Víctor Pérez atisbó la pervivencia en Europa Occidental, de ciertas formas corporativas de representación política, tras el ocaso 
del organicismo social y el desmantelamiento de la práctica totalidad de la economía corporativa nacional. Este autor las denominó, inicialmente, como "neocorporativas", pero más adelante amplió su definición hacía el "mesogobierno". Estas manifestaciones suponían, a su juicio, "políticas de pactos sociales y de intermediación de intereses entre organizaciones sindicales y patronales" con implicaciones políticas (Pérez Díaz, 1987: 95), de naturaleza extraparlamentaria, y supuestamente extraideológica, que representaban mecanismos técnicos que no respondían, exactamente, al modelo tecnocrático popularizado por William H. Smyth ${ }^{31}$, el Estado de Obras de G. Fernández de la Mora, o al sistema de gestión técnica planteado por James Burnham [1905-1987] en su "revolución de los directores" 32 . Aquí podemos encontrar la dimensión prospectiva en la historia del Corporativismo.

Pero una prospectiva que partía de la negación política de "lo corporativo", en función de la vinculación ideológica del pensamiento corporativista con los regímenes perdedores tras la II Guerra mundial. Desparecía la pluralidad histórica antes citada, llegándose a una solución de compromiso para explicar la influencia paraparlamentaria de grupos de intereses: la formulación del concepto de neocorporativismo o corporatismo. Éste surgía como la explicación clave de la característica esencial de la "sociedad organizacional" en las Democracia occidentales. "Nos gobierna esa gran organización que es el Estado, auxiliado y controlado, a su vez, por otras organizaciones un Estado que se ha visto obligado a autolimitar su soberanía a fin de integrarse en organizaciones supraestatales de ámbito planetario y regional”. Pero este examen de Manuel García Pelayo [1909-1991], apuntaba de nuevo el papel técnico del corporativismo, ante los problemas de legitimidad, de soberanía y de representación presentes en la última "crisis del Estado moderno" (García Pelayo, 1991: 1665).

La "neocorporación" era definida como una organización profesional/económica con funciones de complemento técnico en la gestión administrativa, o como una "autoridad funcional" a través de su investidura jurídica por parte del poder público. Así participaban en el proceso de toma de decisiones, situándose como mediación representativa y participativa entre individuo y Estado en numerosas áreas de intervención. El neocorporativismo respondía, pues, al fenómeno de la finisecular de la "revolución organizacional". Con ello la "política neocorporativa" aparecía como uno de los puntos culminantes de la tendencia contemporánea hacia la desideologización de la política ("Estado de obras"). La "nueva Corporación" asumía funciones ejecutivas que complementaba los elementos unitarios (burocracia) e ideológicos (partitocracia) del Estado social ${ }^{33}$; una realidad técnica ya anunciada en los proyectos de la NEP soviética y de la New Deal norteamericana, en las prácticas estalistas del priismo mexicano o del Justicialismo argentino, y en la institucionalización del sindicalismo francés y del sistema de consejos sociales y laborales austriaco. 
"Una buena parte de las actividades estatales tienen una significación económica -señalaba García Pelayo- y una buena parte de las actividades económicas tienen una significación política". Así el neocorporativismo borraba las distinciones entre decisión política y gestión económica actores políticos y actores económicos en muchos sectores públicos; un hecho que alarmaba a parte de la sociedad política por suponer la "intromisión del poder privado en la esfera pública", o por "desvirtuar la acción soberana del legislativo" (Garcia Pelayo, 1991: 21). Pero Wilhelm Röpke [1899-1966] reducía toda expresión corporativa a una manifestación económica colectivista más, otra cara del Estado social intervencionista, "ya que ni la idea romántica de autoadministración económica (Estado de gremios, corporativismo) ni el desarrollo en magna escala de las cooperativas constituyen una alternativa viable ni nos ofrecen un nuevo orden económico que no deba regularse sea por los precios, sea por las órdenes de las autoridades" (Röpke, 1984).

1945 puso fin, a excepción de España, Portugal y varios países hispanoamericanos, al corporativismo estatal como doctrina y como régimen. Mientras en Europa oriental la "liberación" soviética creó "satélites" a su imagen y semejanza, en la parte occidental se desterró el expediente corporativo como recuerdo totalitario $^{34}$. Pero durante la década de los setenta comenzó a analizarse "el papel de los Sindicatos en la nueva sociedad", que Laski (1951) había anunciado a mediados de siglo. Se hablaba ahora del "Neocorporativismo" como paradigma explicativo de la integración política de los nuevos fenómenos de autoorganización social, desde los "grupos de presión" y sindicatos al llamado "Tercer Sector", pasando por las modalidades del movimiento asociativo comunitario. Nacía un nuevo Estado pluralista o "Estado social corporativo" para Charles F. Sabel (1989), que Alan Cawson (1991) definía como "corporativismo liberal y democrático", como mostraba. Miguel Ayuso [1961-] detectó este cambio de rumbo de la teoría corporativa como mediación político-económica; a su juicio surgía como elemento de reorganización técnica de la política demoparlamentaria, y de reconstrucción orgánica de la sociedad a modo de "democracia participativa" (Ayuso, 1996: 167).

El punto de partida de este "debate neocorporativo" lo encontramos en el trabajo de P. Schmitter "Still the Century of Corporatism?" (1974) $)^{35}$. Su tesis, fundada a partir del "paradigma Manoilescu", fue popularizada posteriormente por compilaciones monográficas (como Comparative Political Studies, 1977) y por las polémicas académicas de este autor con G. Lehmbruch o S. Berger; así se retomaban las primeras disquisiciones surgidas el mundo intelectual británico y norteamericano en la década de los sesenta, de la mano de A. Shonfield en 1965, Samuel H. Beer en 1965 o H. Eckstein en 1969 (Sanz Menéndez, 1994). R. Mishra apuntaba que este neocorporativismo se configuró como una especie de "tercera vía", pretendidamente equidistante del socialismo y del conservadurismo (tomando como referente de negociación sindical-patronal del modelo austriaco). Pero una 
vía que fue demasiado optimista en sus predicciones sociológicas (una nueva era de política corporativa parademocrática), tal como se demostró con el agotamiento intelectual de sus debates a finales del siglo XX (Mishra, 1992). Pese a cierta puntualidad de las afirmaciones anteriores, A. L. Sánchez Marín señaló como "tras la Segunda Guerra Mundial se generalizaron en Occidente los pactos socioeconómicos entre organizaciones empresariales y sindicatos de trabajadores", proliferando los Consejos Económicos y Sociales junto a otros órganos consultivos de naturaleza administrativa en los que participan diversos grupos sociales" (Sánchez Marín, 2001).

Ahora bien, los debates sociológicos paralelos sobre el fenómeno "neocorporativo", no llegaron a alcanzar una definición unívoca ni una interpretación común. Significados diversos, y en la mayoría de los casos contradictorios, se han ido sucediendo. De él se derivó una pluralidad de usos y versiones del corporatismo convirtiéndolo en un concepto polisémico, a nivel terminológico y conceptual, que no explicitaba su significado en cuanto a formas y medios específicos de representación en intermediación de intereses (Moreno y Sarasa, 1996). Surgieron tantas definiciones como autores se dedicaron a su consideración: parecía ser una "forma institucionalizada de elaboración de políticas públicas" para Lehmbruch (1979) a la manera de un corporativismo liberal; también aparecía como un nuevo "marco de organización económica estatista" para Pahl y Winkler (1974); asimismo se hablaba de un "sistema específica de ordenación de las relaciones sociolaborales e industriales en torno a la negociación y gestión global de la política salarial" o nuevas redes "de negociación parapolíticas; e incluso era visto como un "nuevo sistema de control capitalista" por L. Panitch (1981).

Sobre esta pluralidad hermenéutica, Heinze y Ulrich señalaban que "no existe acuerdo, por lo demás, sobre si esto señala una evolución general de los Estados capitalistas liberales o si se trata de un fenómeno limitado a países muy determinados (como Austria o Suecia, por ejemplo). El examen de los léxicos científico-sociales y científico-políticos al respecto, "apenas ayudaba a clarificar la espesura conceptual, bien sea porque se ignora el concepto por completo", bien porque se remite al concepto de Estado estamental (especialmente en el ámbito germanoparlante) o al de fascismo (especialmente en los ámbitos inglés y románico, por ejemplo, en la Encyclopedia of the Social Sciences"). Por ello, este debate sobre el corporatism, llevado a cabo especialmente en el ámbito anglófono, impulsó una definición "como tercera línea", como vinculación entre las corporations económicas y la política, dando lugar a "las grandes agrupaciones económicas que dominan el Corporative State" (Heinze y Alemann, 1978: 146). Al respecto, Sánchez Marín establecía, a modo de conclusión, que "el renacer de la representación orgánica se produce tras la segunda guerra mundial, principalmente en forma de representación consultiva y negociada de intereses. Se trata de un corporativismo social y no estatal que se 
nos presenta en complemento con la representación ideológica individual de signo partitocrático" (Sánchez Marín, 2002: 151).

\section{CONCLUSIÓN. PASADO Y PRESENTE DE LA TECNIFICACIÓN DE LA POLÍTICA.}

A modo de epílogo, los fastuosos medios financieros desplegados en la lucha partidista, bien en el Parlamento bien en los medios de comunicación, han generalizado un lenguaje político estandarizado, que en muchas ocasiones esconde o difumina realidades sociales y económicas con traducción o influencia jurídico-política, así como categorías filosófico-políticas existentes más allá de los sistemas consensuados. El aparato burocrático, los gestores técnicos o las prácticas neocorporativas (o "neocorporatistas", utilizando el neologismo anglosajón), el interés personal o grupal, el cursus honorum y o el lobby de presión, son manifestaciones de una tecnificación de la política que afecta, sobremanera, al funcionamiento interno de las diversas modalidades del Estado democrático-parlamentario del mundo occidental.

La Historia, como ciencia social y humana, nos demuestra desde la Begriffgeschichte (Historia de las ideas), el significado de esta tecnificación, en formas corporativas o tecnocráticas, en la Europa contemporánea. Quizás encontremos un fenómeno que nos explica cómo se pretendió organizar la política desde soluciones grupales y laborales; quizás nos enseñe un instrumento jurídico-político que marcó decisivamente la historia de los hombres y mujeres durante gran parte del siglo XX; y quizás nos muestre los movimientos y tendencias que, a inicios del siglo XXI, pueden marcar el análisis político (que atañe al monopolio representativo de las organizaciones partidista de base ideológica), ante los retos económicos globales que afecta a la misma configuración del viejo Estado democrático y nacional europeo.

\section{BIBLIOGRAFÍA.}

Ayuso, Miguel 1996. ¿Después del Leviatán?. Sobre el Estado y su signo. Madrid: Speiro, 1996.

Bizberg, Ilán 1990. Estado y sindicalismo en México. México: El Colegio de México.

Burnham, J. 1962. La revolución de los directores. Buenos Aires: Tall. El Gráfico/Impresores.

Bustamante, J.E. 1988. La República corporativa. Buenos Aires: Emecé.

Campero, Guillermo, y Valenzuela José, 1981. El movimiento sindical chileno en el capitalismo autoritario. Santiago: ILET. 
Carvajal, Patricio 1988. La herencia de Antígono: el derecho de resistencia de Johannes Althusius. Revista de Estudios jurídicos 39: 19-30.

Cawson, Alan 1991. Corporativismo. En Bogdanor, Vernor, Enciclopedia de las instituciones políticas, 177-179. Madrid: Alianza Editorial.

Cole, G.D.H. 1974. La organización política. México: Fondo de Cultura económica.

De Boschi, Renato (ed.) 1991. Corporativismo e Desigualdade. Río de Janeiro: IUPERJ.

Duguit, Leon 1909. La transformación del Estado. Madrid: Francisco Beltrán ed.

Durkheim, Èmile 1982. La división del trabajo social, Madrid: Akal.

Fernández de la Mora, Gonzalo 1986. Los teóricos izquierdistas de la Democracia orgánica. Barcelona: Plaza y Janés.

Fernández Riquelme, Sergio 2005. Corporativismo y política social en el Siglo XX, Un ensayo sobre Mijail Manoilescu. Murcia: Isabor.

Fernández Riquelme, Sergio 2009. La solución corporativa. El derecho político ante el pluralismo social en la era de entreguerras (1919-1945). Pléyade 4: 156.185.

Fernández Riquelme, Sergio 2010. Historia como ciencia. La razón histórica 12: 4-39.

Fortshff, Ernst 1971. Staat und Technik. En Estudio en Homenaje al profesor López Rodó. Madrid.

Furet, F. y Nolte, E. 1998-99. Diálogo François Furet- Ernst Nolte. Hespérides 18 : 947-956.

García Canales, Mariano 1977. La teoría de la representación en la España del siglo XX. Murcia: Publicaciones del Departamento de Derecho público de la Universidad de Murcia.

García Pelayo, Manuel 1991. Las Transformaciones del Estado Contemporáneo. Madrid: Alianza Editorial.

García Pelayo, Manuel, 1991. La sociedad organizacional. En Obras completas, vol. I., 1665-1696. Madrid: Centro de estudios constitucionales.

Gierke, Otto von 1922. Political theories of the Middle Age, Londres: Cambridge University Press.

Gierke, Otto von 1922. Political theories of the Middle Age. Londres: Cambridge University Press.

Gierke, Otto von 1985. Deutsches Privatrecht. Leipzig: Bd/I.

Gurvitch, George 1932. L’Idee du Droit Social. Notion et Système du Droit Social. París : Librairie du Recueil Sirey.

Habermas, Jürgen 1986. Ciencia y Técnica como ideología. Madrid: Tecnos.

Hegel, G. W. F. 1946. Lecciones sobre la Filosofía de la Historia. Buenos Aires: Revista de Derecho privado.

Heinze, Rolf. G. y Von Alemann, Ulrich 1978. ¿Del Estado estamental al corporativismo liberal?. Revista de Estudios políticos 5: 145-156. 
Hofmann, Hasso 2004. La representación en la teoría del Estado premoderna sobre el principio de representación en la Política de Johannes Althusio. Fundamentos. Cuadernos monográficos de teoría del Estado, Derecho público e Historia constitucional 3: S/N.

Incisa, Ludovico 1982. Corporativismo. En Bobbio, N. y Mateucci, N (eds.), Diccionario de política. Vol. I (A-J), 431-436. Madrid: Siglo XXI.

Keiser, Joseph H. 1956. Die Representation Organisierter Interesen. Berlin: Duncker y Humblot.

Koselleck, Reinhart 2001. Los estratos del tiempo: estudios sobre la historia. Barcelona: Paidós.

Lanzaro, Jorge 1998. El fin del siglo del corporativismo. Venezuela: Nueva sociedad editorial.

Laski, Harold J. Los Sindicatos en la nueva sociedad. México: Fondo de Cultura Económica.

Laski, Harold J. 1933. Derecho y Política. Madrid: Edersa.

Laski, Harold J. 2002. La gramática de la política, Granada: Comares.

Lehmbruch, G 1979. Consociational Democracy and the New Corporatism. En Schmitter, P. y Lehmbruch, G. (eds.). Trend Toward Corporatism Intermediation, 147-183. Londres: Sage.

Llorens, E. L. 1993. ¿Qué es la tecnocracia?. Madrid: Editorial Revista de Derecho Privado.

López Amo, Ángel 1953. El proletariado y la cuestión social. Arbor 95: 243-254.

Maier, Ch. 1988. La refundación de la Europa burguesa. Madrid: Ministerio de Trabajo y Seguridad social.

Manoilesco, Mijail 1941. El siglo del corporatismo. El Chileno: Santiago de Chile.

Mishra, R, 1992, El Estado de bienestar en crisis. Madrid: Ministerio de trabajo.

Molina, Jerónimo 2007. Epítome de la Política Social, Murcia: Ediciones Isabor.

Molina, Jerónimo 2007. Epítome de la Política Social, Murcia: Ediciones Isabor.

Montiel, Francisco 1995. F.F. La democracia orgánica. En VVAA, Razonalismo, 231-243. Madrid: Fundación Balmes.

Moreno L. y Sarasa S. 1996. Génesis y desarrollo del Estado de Bienestar en España. Revista Internacional de Sociología 6: 27-69

Negro Dalmacio 1995. La tradición liberal y el Estado. Madrid: Real Academia de Ciencias morales y políticas.

O`Donell, G. 1975. Acerca del corporativismo y la cuestión del Estado. Buenos Aires: CEDES.

Ocampo, Rigoberto (comp.) 1992. La teoría neocorporatista. Ensayos de Philippe Schmitter. Guadalajara: Universidad de Guadalajara.

Pahl, R. E. y Winckler, J. T. 1974. The Corning Corporatism. New Society, 30: 72-76.

Panitch, L. 1981. Trade Unions and the Capitalist State. New Left Review 125: 21-43. 
Pendás, Benigno 1995. El pensamiento político medieval en la teoría del derecho y del Estado de Otto von Gierke. Madrid: Centro de Estudios constitucionales.

Pérez Díaz, Víctor 1987. El retorno de la sociedad civil. Madrid: Instituto de Estudios económicos.

Pontificio Consejo Justicia y Paz 2005. Compendio de la Doctrina Social de la Iglesia. Roma: Libreria Editrice Vaticana.

Posada, Adolfo G. 1891. La teoría de las funciones del Estado. Madrid: Boletín del Instituto libre de enseñanza.

Röpke, Wilhelm 1984. La crisis del colectivismo. Buenos Aires: Emece.

Rosanvallon, Pierre 1998. Le peuple introuvable. Histoire de la représentation démocratique en France. Paris: Éditions Gallimard.

Sabel, Charles S. 1989. La política interna de los sindicatos. En Berger, Suzanne (comp.), La organización de los grupos de interés en Europa Occidental, 259-295. Madrid: Ministerio de Trabajo.

Saint-Simon, Henri de 1975. De la reorganización de la sociedad europea o De la necesidad y de los medios de reunir los pueblos de Europa en un solo cuerpo político conservando a cada uno su independencia nacional. Madrid: Instituto de Estudios Políticos.

Sánchez Marín, A. L 2002. La representación orgánica. Razón española 112: 197-199.

Sánchez Marín, A.L. 2011. Supuestos y principios fundamentales de la representación pública mixta. Oviedo: Editorial Septem.

Sanz Menendez, Luis 1994. El corporatismo en las sociedades industriales avanzadas: veinte años de debates sobre intermediación de intereses y políticas públicas. Madrid: CSIC.

Schmitt, Carl 1998. El Estado como concepto vinculado a una época histórica. En Veintiuno 39: 67-82.

Schmitt, Carl 1999. El concepto de lo político. Madrid: Alianza editorial.

Schmitter, P.C. 1978. Reflections on Mihail Manoilesco and the Politicals Consequences of Delayeddependent Development on the Periphery of western Europe. En Kenneth, Jowie (ed.), Social Change in Romania (1860-1940). Berkeley: Institute of International Studies.

Spirito, Ugo 1970. II corporativismo. Firenze: Sansoni.

Von Stein, Lorenz 1981. Movimientos sociales y Monarquía. Madrid: Centro de Estudios Constitucionales.

Weber, Max 1981. El político y el científico, Madrid: Alianza editorial.

\section{Citas y Notas}

1 Este trabajo supone una revisión historiográfica de mi tesis sobre el Corporativismo como Política social, presente en varios trabajos previos sobre el tema (Fernández Riquelme, 2005; 2009). 
2 Esta era, en esencia, la finalidad originaria del Corporativismo: la consecución de un orden social orgánico y solidario, necesitaba de un orden económico capaz de volver a unir a los "productores", de una Corporación destinada a reflejar esa armonía interclasista en la Sociedad. La Corporación volvería a vincular de nuevo "al trabajador a su familia y a la obra de su trabajo", volvería el "espíritu gremial". Trabajo y Capital, Obreros y patronos colaborarían -según A. López-Amo [1917-1956] - desde la actividad productiva en la organización de la sociedad al "suprimir la oposición de los campos antagónicos para establecer en su lugar la cooperación de todos los elementos que integran una rama de la producción” (López Amo, 1953: 243).

3 Jurista polémico, y hasta cierto punto "maldito", por su colaboración con el régimen nacionalsocialista, pero cuyo retrato del pluralismo social del siglo XIX, enfrentado a su teoría del Estado, es sumamente ilustrativo del fenómeno.

4 La objetividad de todo hecho histórico debe señalar como cada concepto político, social o económico creados por toda cultura, no son universales ni eternos; resultan, empero, instrumentos de la "razón histórica" propia de una generación consciente de su unidad y trascendencia. Poseen, utilizando una analogía orgánica, una "existencia histórica" determinada, ligada a la realidad humana que los ha generado. La finalización de su tiempo histórico, del conjunto de creencias, de sus "categorías del espíritu", es su propio ocaso. Los conceptos con lo que se comprende la realidad del pasado representan esta naturaleza, y su agotamiento histórico viene precedido de la quiebra de los modos de pensamiento imperantes. En un proceso que pasa generalmente inadvertido a los coetáneos, no así al historiador (o por lo menos debería), la mutación del punto de vista esencial (económico, político, social, cultural) de una generación, y que da carácter a una época, presupone un cambio en el mundo, en sus instituciones y su sistema de creencias; creencias donde el hombre situaba su razón de ser, ya que "su matriz albergaba su tiempo biográfico" (Fernández Riquelme, 2010).

5 El primer artículo de la citada ley rezaba así: « L'anéantissement de toutes espèces de corporations des citoyens du même état ou profession étant une des bases fondamentales de la constitution française, il est défendu de les rétablir de fait, sous quelque prétexte et quelque forme que ce soit »; y el segundo lo siguiente : «Les citoyens d'un même état ou profession, les entrepreneurs, ceux qui ont boutique ouverte, les ouvriers et compagnons d'un art quelconque ne pourront, lorsqu'ils se trouveront ensemble, se nommer ni président, ni secrétaires, ni syndics, tenir des registres, prendre des arrêtés ou délibérations, former des règlements sur leurs prétendus intérêts communs».

6 Asimismo, Heinrich con Kleist [1777-1811], Karl Wilhelm Friedrich Schlegel [1772-1829], Joseph Görres [1776-1848], Adam H. Müller [1779-1829] o Friedrich von Gentz [17641832] desarrollaron las líneas maestras del VerbändenStaat: la sociedad era una analogía organizativa y colectiva del mismo cuerpo humano o del propio orden divino, y que debía tener una representación consecuente en las instituciones políticas de la Nación. El equilibrio medieval había sido roto por la Ley Le Chapelier francesa (1791) y las Combination Laws inglesas (1799), la sanción de la obra antigremial presente en los primeros fisiócratas y liberales (Adam Smith), que consideraban incompatibles las regulaciones corporativas y la innovación tecnológica. A estos nombres podemos unir el del filósofo Heinrich Ahrens [1808-1874] por su influencia en España gracias a la difusión hecha por Julián Sanz del Río [1814-1869] de sus textos Curso de Derecho natural (1839) y La Enciclopedia (1855), reintepretaciones de las tesis organicistas de Karl Krause [1781-1832] y sus obras capitales, 
Vorlesungen über das System der Philosophie (1828) y Urbild der Menschheit (1811). Véase Sánchez Marín (2002).

7 Sobre la obra de von Gierke en español véase a E. Wolf, Von Ihering-Von Gierke. Madrid Editorial Revista de Derecho Privado, s.f. (traducción de A. Truyol y Serra).

8 Sobre el pensamiento de Johannes Althusio podemos señalar los estudios de Carvajal (1998).

9 La idea medieval de Universo como "organismo" que equiparaba Divinidad y Tierra se concretaba en la Teocracia como "doctrina social medieval"; para Gierke esta, a su vez "equiparaba a Dios y al Estado". Así, el Microcosmos y el Macrocosmos vivían en una perfecta armonía (Gierke, 1922: 1-2).

10 Esta fusión entre la "la unidad y el equilibrio" conllevaba en Gierke la visión teológica de la sociedad medieval como un "organismo". La unidad era el "principio constitutivo del universo" (principium unitatis de "Dios como uno"), por lo que se derivaba, a través de la escolástica, la obligatoriedad de un "gobierno uniforme del mundo" (unicus principatus de una ley y un gobierno). Como reflejo humano del "orden divino", la humanidad se ordenaba en una "Comunidad orgánica" formada sobre distintos cuerpos funcionales, y bajo dos "ordenes de vida": el espiritual (Iglesia) y el temporal (Estado). Por ello, y retomando la tradición filosófica del Medioevo, las corporaciones o "cuerpos" nacían, a partir de la tradición germana, como límite del poder absoluto de la Iglesia (ecclesia universalis) o como Imperio (republica generis humanis). Así "el cuerpo político" temporal tenía existencia propia, no por legitimación papal o imperial, sino dentro del orden orgánico humano hecho por Dios, y con "funciones definidas" (Gierke, 1922: 13).

11 La "preferencia medieval" por la Monarquía residía, según Gierke, en la consideración del Monarca como imagen del mismo "Dios", portador de sus valores supremos pero "representación limitada del señorío divino" (Gierke, 1922: 33).

12 Los rasgos esenciales de esta nueva Filosofía y este nuevo Derecho medieval eran para Gierke el concepto común del universo como "unidad" divina, la sociedad concebida como "organismo" reflejo de esa"totalidad" y compuesta de "cuerpos sociales", idea teocrática de identificación entre Dios y Estado, y labor cooperativa entre los cuerpos sociales en busca de la "armonía divina" (Gierke, 1922: 2-6).

13 Pero toda esta teoría debía, en última instancia, de la obra de uno de los maestros: el jurista romano-germanista Georg von Beseler. Así se muestra en Das Deutsche Genossenschaftrecht (1871), que contiene para Benigno Pendás, un organicismo social comunitarista que determinaba una concepción positivista, pangermánica y antirromanista del Derecho natural. Sus corporaciones, órganos jurídicos de relación entre pueblo y poder organizado (de la Iglesia universal al Estado secularizado), respondían al modelo generalizado en el Medioevo, tal como desarrollaba en Labands Staatsrecht un die deutschce Rechtswissenschaft (1883). Las normas del Derecho natural escapaban, para Gierke, a los poderes supremos del Emperador y del Papado, "por encima del gobernante y del pueblo soberano, e incluso, por encima de la comunidad de mortales", ya que "sus principios eran eternos e indestructibles" (Pendás, 1995: 14).

14 Ya en 1803 publicó las Cartas de un habitante de Ginebra a sus contemporáneos, donde se manifestaba a favor de una "sociedad científica" que orientase la labor de los industriales. 
Años más tarde, desde su revista La Industria literaria y científica [1816-1818] expuso los principios del "socialismo industrialista": la industria y la ciencia positiva como las dos únicas formas de vida temporal y espiritual capaces de dirigir la sociedad. Así, en De l' industrie (1817) y en Catécisme des Industriels (1819) postulaba la figura del "industrial" como el medio para "salvar la Republica francesa tras la revolución"; era el protagonista indiscutible de la fase actual de desarrollo histórico de la civilización europea. Paralelamente, en varios cuadernos de su colección El Político dirigido por una sociedad de ciencias y letras [1818-1819] fundía la política y la economía en una nueva "ciencia de la producción". Si la industrialización establecía las modernas relaciones y puestos sociales, la política y las leyes debían estar regidas, no por sacerdotes o militares, funcionarios o nobles, sino por técnicos industriales y científicos. Sobre este sistema, el ingeniero Henri Farol [1841-1925] levantaría su teoría de gestión técnica (Administración industrial y general, 1916), que tanta influencia tendría en los posteriores postulados políticos tecnocráticos. Por ello llegó a defender en 1814 la federación de las sociedades industriales europeas (Saint-Simon, 1975).

15 Dentro de sus primeras creaciones, en la Alemania católica destacó la figura del obispo de Maguncia Wilhelm E. von Ketteler [1811-1877], autor de Arbeitsfrage und das Christentum y promotor de diversas centrales corporativas sindicales (Berufsgenossenschaftten, 1889), siguiendo la estela del agrarista P. Kolvihn. En la vecina Francia jugaron un papel fundamental los primeros Centros de estudios sociales y obreros católicos; entre ellos destacó el "Conseil d'etudes" patrocinado por A. de Mun y R. la Tour du Pin, y la "Unión de Malinas" [1884-1891], nombre dado a "L’Union Catholique d'Etudes Sociales et Economiques", verdadero referente del corporativismo obrero y económico en torno a la figura de Gaspard Mermillod [1824-1892] En el mismo país galo destacó la experiencia práctica de Leon Pierre Harmel [1829-1915], fundador de una de las primeras corporaciones católicas, experiencia que volcó en su obra Manual de la corporación cristiana (1879). A estas tareas se sumó la revista de los Círculos católicos, la Association Catholique, impulsora mediática del proyecto de unión y difusión de estos Círculos sobre un "Grand Conseil des Corporations".

16 Sobre el conjunto de textos católicos sobre la Cuestión social véase Pontificio Consejo Justicia y Paz (2005).

17 La Encíclica Rerum Novarum, cifrada en el análisis religioso sobre la condición de los obreros, núcleo del posterior Congreso de Vicenza, se desarrollaba a través de la exposición de tres partes: exposición inicial de la Cuestión social (el "mal social"), ataque posterior de la "falsa solución socialista", desarrollo de los "verdaderos remedios", basados en la intervención de la Iglesia mediante su doctrina (“justicia, caridad y fraternidad") y su acción (intervención del Estado que justifica, regula y limita; y de los intereses de las asociaciones profesionales fundadas en el Derecho natural, impulsando asociaciones católicas en el campo sindical y profesional).

18 Por ello, en un primer nivel sociológico se negaba la tradición origen roussoniana, el llamado "contrato social" y se retomaba un ideal organicista común a distintas escuelas católicas, tradicionalistas, idealistas y funcionales. Este nivel nos conecta directamente con un segundo de carácter politológico, que cuestionaba los modelos partidocráticos de intermediación política y social, ajenos a las necesidades y realidades de esta visión orgánica de la sociedad. Una sociedad con "poderes múltiples" no podía ser representada por un poder político único, el Estado totalitario (monismo político), ni por una soberanía única controlada por grupos ideológicos, el Estado de partidos (democracia inorgánica) (Montiel, 1995: 233). 
19 Laski negaba todo derecho de propiedad de "la autoridad y la soberanía" a la forma política estatal; solo se concedía su uso en función del cumplimiento de determinados fines, de determinados principios legales por encima de él mismo. El Estado no era la encarnación de una voluntad general indiferenciada, sino la suma de "pluralidad de voluntades" unidas entre sí en fines e identidades comunes; por ello, para Laski, los derechos políticos, la ley, se fundaban en relación al cumplimiento de ciertos deberes sociales Los derechos derivaban solo de las funciones sociales desarrolladas; la función estaba implícita en el derecho, y el Estado se limitaba a ensamblarlas en una comunidad solidaria y cohesionada (Laski, 1933: 257).

20 Esta primera aportación debía, en gran medida, de la vertiente corporativa del pluralismo, desarrollada por la obra de Gierke y los trabajos de F.W. Maitland, J.N. Figgis y H. Krabbe; una línea fundada en la personalidad y autonomía decisoria de las corporaciones antes y dentro del Estado. La pluralidad de lealtades e identidades grupales en el seno de la comunidad social, necesitaba, en función del principio de solidaridad orgánico o positivo, de una autoridad política capaz de mantener la unidad y respetar jurídicamente las "autarquías sociales. El ámbito de la política, en su contenido y en su forma, no se limitaba al Estado, sino a otras instancias de la sociedad. (Gurvitch, 1932).

21 Von Stein situó el nacimiento de las doctrinas sociales en 1848, a partir de los hechos acaecidos en Francia; en ellos detectó como el "trabajo" no sólo se significaba como el medio natural de superar las limitaciones de la naturaleza humana, sino como sería el criterio político futuro. La Gesellschaft nacida de la Revolución industrial superaba los viejos límites comunitarios de la Gemeinschaft, y a su vez anulaba progresivamente la antinomia fundamental "Estado-Sociedad". En la comunidad tradicional, en trance de superación para Von Stein, y definida como "unidad de voluntad y de acción", el Estado representaba a la "persona" (vehículo de autodeterminación, reino de la libertad) y la Sociedad actuaba como "objeto" (vida autónoma con leyes propias). Ahora "la sociedad como organización" interrelacionaba totalmente las esferas autónomas de lo político y de lo económico; se desbordaba el "equilibrio" entre ambas esferas: la oposición permanente entre lo político como "reino de la libertad" y lo social como "infraestructura de sujeción económica” (Von Stein, 1981: 56).

22 Para Mishra constituyó un modelo propio de Política social, al presuponer una solución total al problema de las discrepancias entre lo económico y lo político: el modelo corporativo contempla de una manera global las relaciones entre relaciones de Mercado, pleno empleo y garantías sociales (Mishra, 1992).

23 Si la revolución industrial liberal logró el reconocimiento público de derechos económicos fundamentales de naturaleza individual, desde esta fecha se plantearán derechos económicos de tipo social (derechos sociales), y entre ellos, los de tipo corporativo. Ya no bastaba con la abstención del Estado liberal doctrinario de 1830; el poder público debía de reconocer la existencia de un poder económico y social plural, ante el cual la no intervención conduciría al estallido de conflictos sociales y económicos internos. Pero el Estado asistencial y protector erigido por Otto von Bismarck a finales del siglo XIX tampoco era la solución. El Estado o se convertía en instrumento técnico, organizador u ordenador, de la sociedad orgánica, o debía desaparecer dejando paso a nuevas formas políticas comunitarias (Duguit, 1909: 195).

24 Tomado como referencia la obra de Joseph H. Keiser (1956), señalaba que "el intrincado sistema de intereses organizados permite la representación política de los egoísmos y sus lobbyes" que niegan "la razón objetiva" de lo político y el Estado el en "totalismo de un partido" (Schmitt, 1998: 67-68). 
25 El trabajo organizado podía y debía adquirir representación política específica. Socialistas, liberales o democristianos lo postulaban Comisiones técnicas, Organismos paritarios, Parlamentos industriales o Senados de representación corporativa, que se sucedían sin que la III República francesa y la República de Weimar alemana (o más tarde la II República española) fueran más allá de un limitado corporativismo de Estado (Rosanvallon, 1988: 245).

26 Sobre esta categoría historiográfica véase Furet y Nolte (1988-89 : 947).

27 El filósofo italiano Ugo Spirito [1896-1979] defendía en su conferencia “corporativismo e libertà" (presentada en 1935 en el Convegno italo-francese di studi corporativi de Roma), la "collaborazione gerarchica" entre Estado y Corporación para generar el fundamento de la "nuova società": "para poder vencer al capitalismo se necesita vencerlo técnica y espiritualmente, no con la violencia del número, sino con la superioridad técnica de una jerarquía totalitaria" (Spirito, 1970: 356).

28 La tesis de este estudio partía de un hecho de enorme actualidad en la Europa de esos años: "la doctrina tecnocrática, que ha obtenido enorme resonancia allende el Atlántico, es una de las manifestaciones de la mentalidad postbélica orientada hacia la dictadura". Esta doctrina conllevaba para Lloréns la directa "despolitización de la actividad estatal", en manos ahora de gestores y directores cualificados. El paradigma funcionalista derivado de la moderna división y maquinización del trabajo se trasladaba a la actividad política, como a su juicio se asumía en la legislación Norteamérica (Nacional Industrial Recovery, 1932). En su indagación sobre los creadores de la noción tecnocrática (William H. Smyth, Thorstein Veblen) y sus seguidores (Lobe, Laing, Bellamy, Porter, Lardiner), manifestaba el autor un cierto rechazo de las bases mecanicistas que los criterios de eficiencia de las "leyes productivas" introducen en la gestión política; la sacralización de la "Administración técnica"; y la idea de que "las ciencias físicas han superado a las sociales" (Llorens, 1933)

29 La literatura hispanoamericana sobre el Corporativismo es notable, especialmente en México, Chile, Venezuela o Brasil. Así podemos destacar los textos de Bustamante (1988), Campero y Valenzuela, (1981).O’Donell (1975), De Boschi (1991) o Lanzaro (1988).

30 Sobre el modelo corporativo instaurado desde 1917 por el PRI apuntamos las obras de Bizberg (1990) y Ocampo (1992).

31 Este autor acuñó y desarrolló el neologismo Technocracy en varios ensayos publicados en la revista Industrial Management..

32 En su obra The Managerial Revolution. What is hapening in the World?, 1941 (Burnham, 1962).

33 "El Estado no se justifica por la gracia, al modo luterano, sino por las obras, al modo romano. El buen Estado es siempre un Estado de obras”. Fernández de la Mora situaba así las claves técnicas y orgánicas de una tendencia neocorporativa en la definición del Estado del Bienestar (Fernández de la Mora, 1986).

34 Heinze y Alemann apuntaban al respecto que "todavía no hace mucho tiempo que se liquidaron - curiosamente con escasa resistencia- las Cortes españolas, reliquia de la Constitución estamental y corporativa, casi olvidada en la teoría constitucional de Europa occidental. Los sistemas constitucionales estamentales se han desacreditado de tal modo con el fascismo, que sus restos - tanto tiempo conservados en la Península Ibérica - se han 
podido transformar sin necesidad de nueva guerra civil en la dirección de una forma moderna de gobierno de la democracia liberal y parlamentaria" (Heinze y Alemann, 1978: 147-148).

35 A partir de sus estudios sobre los grupos de interés en Iberoamérica ("Interest conflict and political change in Brazil”, 1971), Schmitter planteó su teoría del fenómeno corporativo de representación de intereses, tomando como referente los regímenes autoritarios iberoamericanos. Schmitter detectó un "pluralismo limitado" definido como "regimentación desde arriba de la representación de los intereses en un conjunto preordenado de categorías jerárquicas; reconocimiento oficial y control sobre las finanzas internas; la selección de líderes y la articulación de demandas; monopolio formal de representación; imposición de una relación simbiótica entre esas asociaciones semivoluntarias y la burocracia central", sobre una estructura organizativa autoritaria de partido político único, centralización administrativa y despolitización tecnocrática (Schmitter, 1978).

\section{ACERCA EL AUTOR}

Sergio Fernández Riquelme: Profesor de Historia e Investigación social. Doctor en Sociología y Política Social. Universidad de Murcia (España). 